\title{
MASTER
}

\section{Errors in Measuring Level and Density with Purged Dip Tubes}

\author{
N. C. Bradley \\ W. P. Murray \\ J. M. Googe
}

APPLIED TECHNOLOGY

Aay further distribution by any holder of this decument or of the data therein to third parties representing foreign interests, foreign governments, foreign companies and fereign subsidlaxies or foreign divisions of U.S. conseanies should be coordinated with the Pirector,

Division of Reactor Research and Development, Qepartment of Energy.

\section{This document is}

PUBLICLY RELEASABLE

David Hamrin, ORNL

Authorizing Oficial

Date 2-5-2013

\section{OAK RIDGE NATIONAL LABORATORY} OPERATED BY UNION CARBIDE CORPORATION · FOR THE DEPARTMENT OF ENERGY 
Printed in the United States of America. Available from National Technical Information Service

U.S. Department of Commerce 5285 Port Royal Road, Springfield, Virginia 22161

Price: Printed Copy $\$ 4.00$; Microfiche $\$ 3.00$

This report was prepared as an account of work sponsored by an agency of the United States Government. Neither the United States Government nor any agency thereof, nor any of their employees, contractors, subcontractors, or their employees, makes any warranty, express or implied, nor assumes any legal liability or responsibility for any third party's use or the results of such use of any information, apparatus, product or process disclosed in this report, nor represents that its use by such third party would not infringe privately owned rights. 


\section{DISCLAIMER}

This report was prepared as an account of work sponsored by an agency of the United States Government. Neither the United States Government nor any agency Thereof, nor any of their employees, makes any warranty, express or implied, or assumes any legal liability or responsibility for the accuracy, completeness, or usefulness of any information, apparatus, product, or process disclosed, or represents that its use would not infringe privately owned rights. Reference herein to any specific commercial product, process, or service by trade name, trademark, manufacturer, or otherwise does not necessarily constitute or imply its endorsement, recommendation, or favoring by the United States Government or any agency thereof. The views and opinions of authors expressed herein do not necessarily state or reflect those of the United States Government or any agency thereof. 


\section{DISCLAIMER}

Portions of this document may be illegible in electronic image products. Images are produced from the best available original document. 
ORNL/TM-5995

Dist. Category UC-79c

Contract No W-7405-eng-26

\section{ADVANCED FUEL RECYCLE PROGRAM}

\section{ERRORS IN MEASURING LEVEL AND DENSITY WITH PURGED DIP TUBES}

\section{$\because$ 'als wowmen is - SLLLYY RELEASABLE Dowid Hamrin, ORNL 4uthorizing Conicial $2-5-2013$}

N. C. Bradley ${ }^{1}$

W. P. Murray ${ }^{1}$

J. M. Googe 2

1. Instrumentation and Controls Division

2. Consultant, University of Tennessee

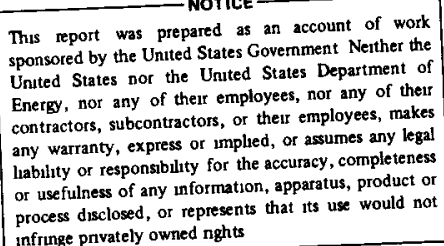

ecount of work Ded any of their contractors, subcontractors, any warranty, express or for the accuracy, completeness or usefulness of any information, apparatus, product or infrunge privately owned nghts

Date Published - November 1977

NOTICE: This document contains information of a preliminary nature. It is subject to revision or correction and therefore does not represent a final report.

\section{OAK RIDGE NATIONAL LABORATORY \\ Oak Ridge, Tennessee 37830 operated by UNION CARBIDE CORPORATION for the DEPARTMENT OF ENERGY}

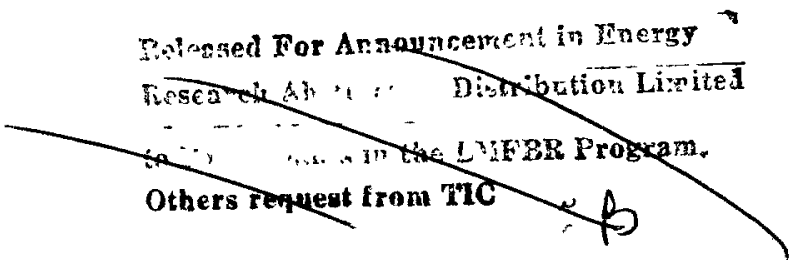




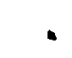




\section{CONTENTS}

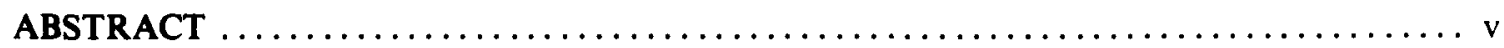

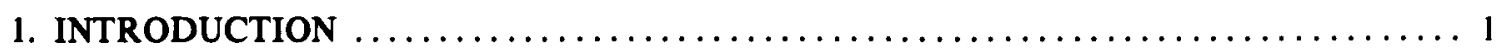

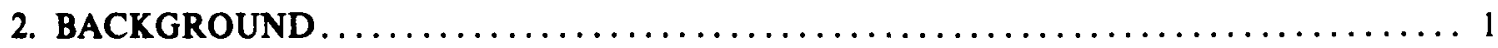

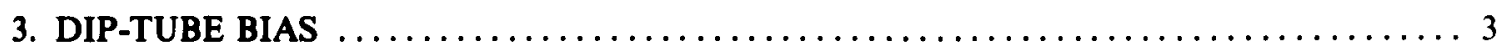

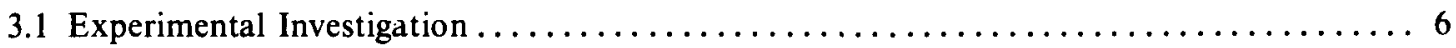

4. OTHER INSTRUMENTATION SYSTEM ERRORS $\ldots \ldots \ldots \ldots \ldots \ldots \ldots \ldots \ldots \ldots$

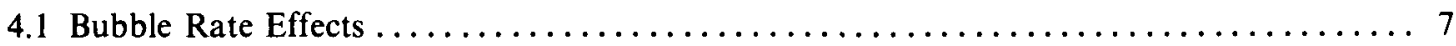

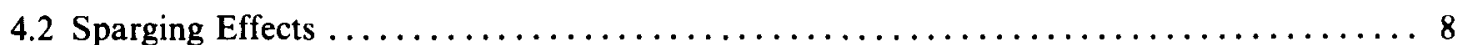

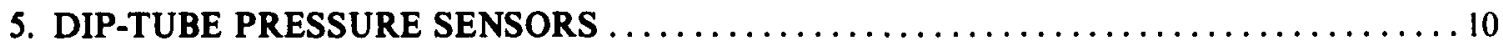

6. ERRORS DUE TO TANK GEOMETRY AND TEMPERATURE $\ldots \ldots \ldots \ldots \ldots \ldots \ldots$

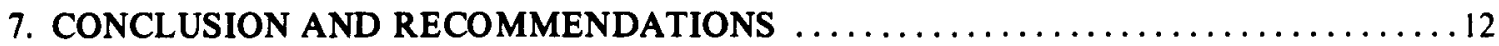





\begin{abstract}
Measurement of liquid level and density with dip-tube sensors was evaluated by analysis and experiment. A model was developed to predict the characteristic error caused by the purge-gas bubble (dip-tube bias). Experimental results are presented to support these predictions and are also compared with data reported in the literature. It was shown that properly designed and calibrated dip tubes do not make significant contributions to the error in dip-tube level and density-measurement systems.
\end{abstract}




\section{INTRODUCTION}

Levels and densities are measured on most process liquids stored in tanks within a radiochemical reprocessing plant. These measurements are usually made by measuring a differential pressure across gas-purged dip tubes placed into the liquid. This analysis was performed with a purged dip tube to see if improvements in the accuracy of level and density measurements can be obtained using existing or new techniques. In the past, the accuracy of level and density measurements has been limited by the accuracy of the differential pressure instrument in the system. However, improvements in differential pressure transducers have caused new interest in dip-tube system errors to determine the major contribution to and limiting factors of total system error.

Level and density measurement errors will contribute to system errors in controlling density, flow, and concentration variables in the Advanced Fuel Recycle Program.

\section{BACKGROUND}

The pressure in a column of fluid above a reference point where a pressure measurement can be made has long been recognized as a convenient parameter for inferring the height of the liquid. Figure 1 shows such a level-measuring system; the dip tube is kept free of the liquid in the tank by slowly purging it with a gas and thereby establishing the gas pressure inside the tube as exactly equal to the fluid pressure at the tip of the purge tube where the bubbles are forming.

For low purge gas flows, the bubbles are slowly forming at the purge gas-water interface at the tip of the tube. Thus, the pressure drop in the tube due to such gas flows can be neglected, and

$$
P_{\text {tube }}+\int_{0}^{h} g \rho_{\text {gas }}(z) d z=\int_{0}^{h} g \rho_{\text {flud }}(z) d z+P_{0} .
$$

If the fluid density is uniform, then (1) is reduced to

$$
P_{\text {tube }}+\int_{0}^{h} g \rho_{\text {gas }}(\mathrm{z}) d z=g \rho_{\text {fluid }} h+P_{0} .
$$

The second term on the left of Eq. (2) involves the weight of the column of gas in the dip tube and is subject to the effect of density changes in the gas. Errors caused by gas density changes are an order of magnitude smaller than those caused by gas bubble effects and therefore are not included in this study. ${ }^{1}$

Neglecting the effect of density variations allows Eq. (2) to be written

$$
P_{\text {tube }}=P_{0}+h g\left(\rho_{\text {fluid }}-\rho_{\text {gas }}\right)
$$


ORNL-DWG 77-11833

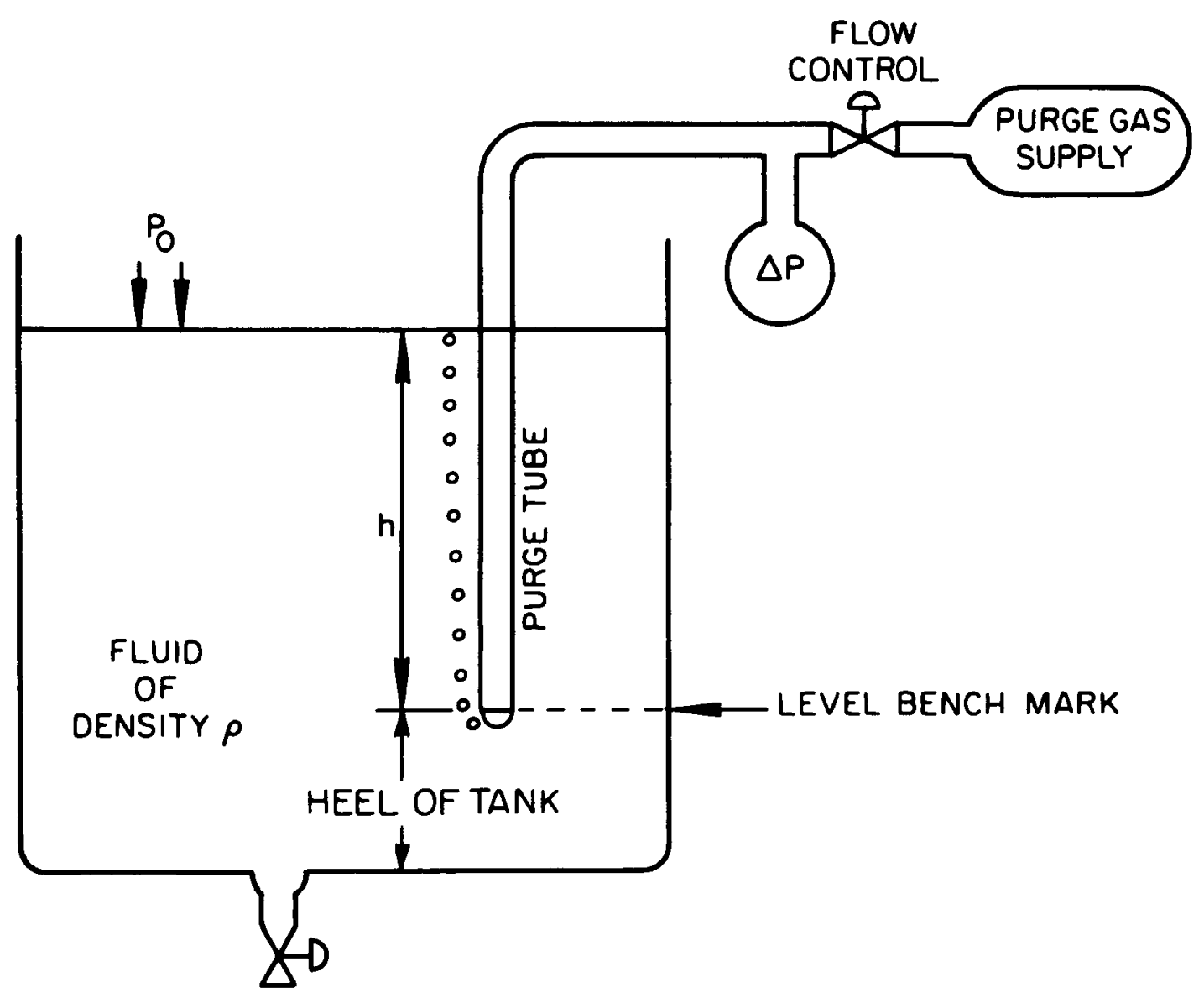

Fig. 1. Liquid-level measuring system.

or

$$
P_{\text {tube }}=P_{0}+h \rho_{D} g, \text { where } \rho_{D}=\rho_{\text {fludd }}-\rho_{\text {gas }} .
$$

The pressure in the dip tube is usually measured by a differential pressure transducer referenced to atmospheric pressure such that

$$
h=\frac{P_{\mathrm{tube}}-P_{0}}{\rho_{D} g}=\frac{P}{\rho_{D} g},
$$

where $h$ is the level in the tank above the heel, and $P$ is the gauge pressure in the dip tube.

If two purged dip tubes are used (Fig. 2), it is easy to see that the pressure difference between the gas in the tubes is proportional to the liquid density of the fluid in the tank,

$$
\rho=\frac{\triangle P}{\left(h_{2}-h_{1}\right) g} .
$$




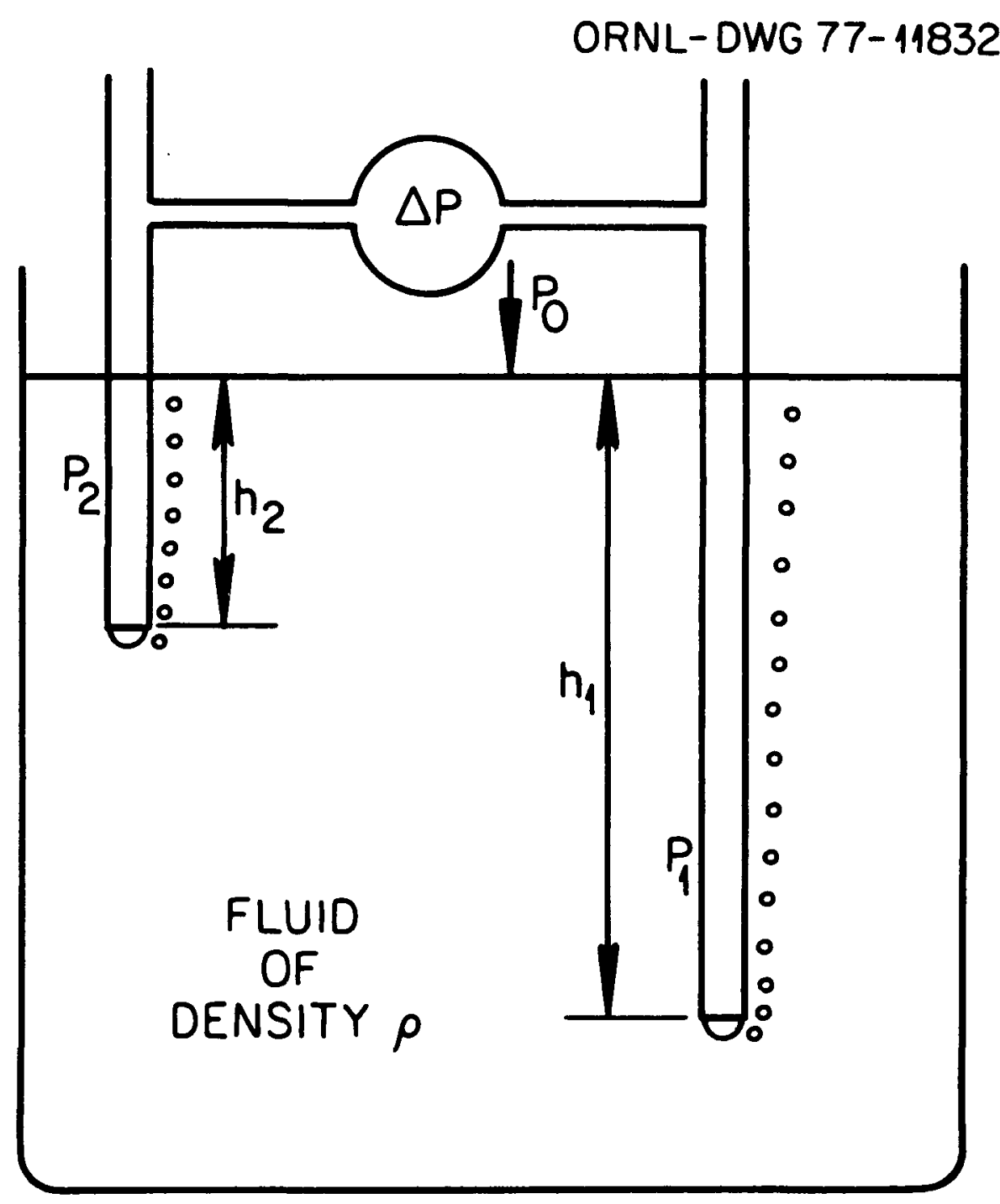

Fig. 2. Fluid density measuring system.

A principal limitation in the resolution of liquid-level measurements, which has long been recognized, comes from the gas pressure required to overcome the surface tension and bouyancy forces while blowing the bubbles at the tip of the dip tube. This uncertainty is a periodic pressure wave and its effect is known as "dip-tube bias."

\section{DIP-TUBE BIAS}

The flow of gas in the purge tube must be a very small laminar flow to establish the gas fluid interface at exactly the tip of the dip tube, but not so large as to introduce a pressure gradient between the tip of the tube and the pressure-sensing point. However, such a flow will cause small periodic fluctuations in gas pressure as the bubbles form and detach at the end of the tube.

The pressure within a bubble can be calculated and will yield results very close to those measured in the laboratory. The absolute pressure within a spherical bubble for Newtonian fluids at 
the end of a dip tube has been reported. ${ }^{2}$ Pressures within a spherical bubble and other physical properties were studied during the latter part of the 19th century and first part of the 20th century in research on surface tension and are directly applicable to the dip-tube bias problem.

Figure 3 shows a spherical bubble of radius $r$ at the end of a dip tube of radius $r_{T}$. The absolute pressure within the tube and bubble, $P_{B}$, is related to the other parameters by the equation

$$
P_{B}=P_{0}+\frac{2 \gamma}{r}+g \Delta h \rho_{D}+g h \rho_{D}
$$

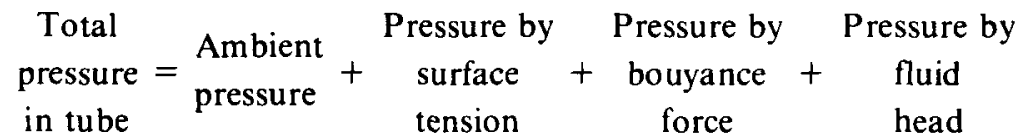

The dip-tube bias is seen to be made up of the pressure caused by the surface tension and bouyance forces:

$$
P_{D T B}=\frac{2 \gamma}{r}+g \triangle h \rho_{D}
$$

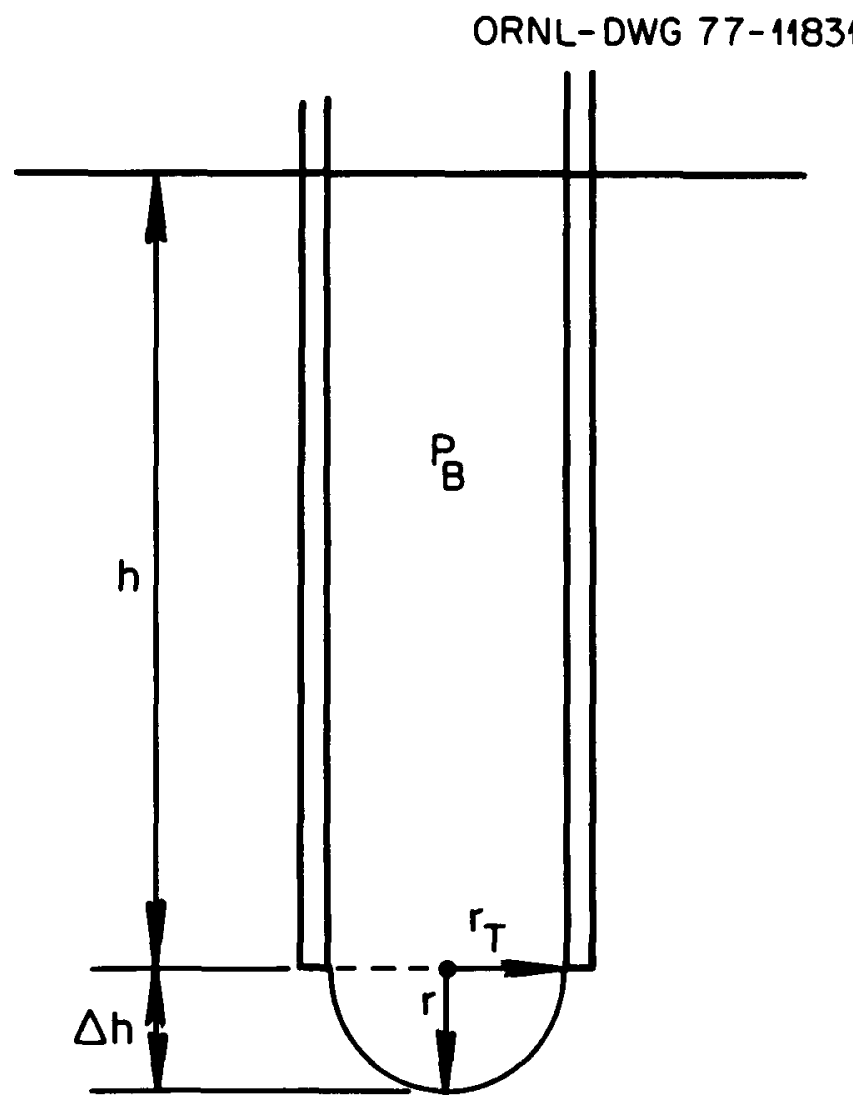

Fig. 3. Physical relationships within a spherical bubble. 
where

$$
\begin{aligned}
\gamma & =\text { surface tension between two fluids, } \\
\gamma & =0.00498 \mathrm{lb} / \mathrm{ft}=72.8 \mathrm{dyne} / \mathrm{cm} \text { for air-water at } 68^{\circ} \mathrm{F}, \\
\mathrm{g} & =\text { gravitational acceleration }=32.2 \mathrm{ft} / \mathrm{sec}^{2}=980 \mathrm{~cm} / \mathrm{sec}^{2}, \\
\rho_{D} & =\text { difference in mass density of two fluids, } \\
\mathrm{r} & =\text { radius of bubble. }
\end{aligned}
$$

Ada $^{2}$ argues that when a bubble is blown at the end of a vertical tube dipping into a liquid, the bubble will have the form of a segment of a sphere if the radius of the tube is small. The radius of this sphere will at first decrease until the bubble becomes hemispherical. Further growth of the bubble will increase the radius. The equation for the pressure within a spherical bubble due to surface tension forces is

$$
P_{\text {bubble }}=\frac{2 \gamma}{r}
$$

Hence, this pressure is maximum for a minimum radius, which occurs when the bubble radius is exactly equal to the tube radius. Thus, Adam argues that the maximum attainable pressure in the bubble occurs when $\Delta h=r_{\text {tube. }}$ Therefore, the maximum dip-tube bias is given by Eq. (8) with $\Delta h$ $=r_{T}$ :

$$
P_{D T B}=\frac{2 \gamma}{r_{T}}+\rho_{D} g r_{T}
$$

Laboratory observations do indeed show that the bubble grows until it becomes a hemisphere about the size of the tube, at which time it becomes unstable and detaches from the end of the tube. Adam points out that this is the size at which the maximum pressure is reached, and a larger radius causes a decrease in pressure.

Equation (10) gives the maximum bias as a function of dip-tube radius $r$ and, when examined, is seen to have a minimum value. This means there is an optimum tube radius for each gas-fluid system. Equation (10) can be differentiated and set to zero.

$$
\frac{\partial P_{D T B}}{\partial r_{T}}=-\frac{2 \gamma}{r_{T}^{2}}+\rho_{D} g=0
$$

yielding

$$
r_{\min }=\sqrt{\frac{2 \gamma}{g \rho_{D}}}
$$


This optimum value of tube radius defines a minimum bias as

$$
P_{D T B}^{\min }=\sqrt{8 \gamma g \rho D}
$$

Figure 4 is a plot of Eq. (10) for an air-water system revealing the optimum radius of 0.152 in. given by Eq. (12). The minimum bias of 0.3 in. of $\mathrm{H}_{2} \mathrm{O}$ is also shown.

\subsection{Experimental Investigation}

Tests were run on an air-water system using a high-speed pressure transducer to observe the dip-tube bubble formation. A study at ORNL by M. J. Kelly ${ }^{3}$ also contains experimental data showing a plot of maximum dip-tube bias vs tube diameter.

Both laboratory data obtained in this study and Kelly's data agree well with the spherical model data for tube sizes up to the optimum size. Figure 5 shows that for larger tubes the predicted increase in bias is not found to be real. When tube diameters larger than those given by Eq. (12) are tested, the bubbles are noticeably elliptical. A model based on elliptical bubbles has not been evolved; however, arguments are substantive to explain the departure of experimental observations from those predicted by the spherical model. The spherical model predicts an optimum tube size that agrees well with the minimum tube size found experimentally.

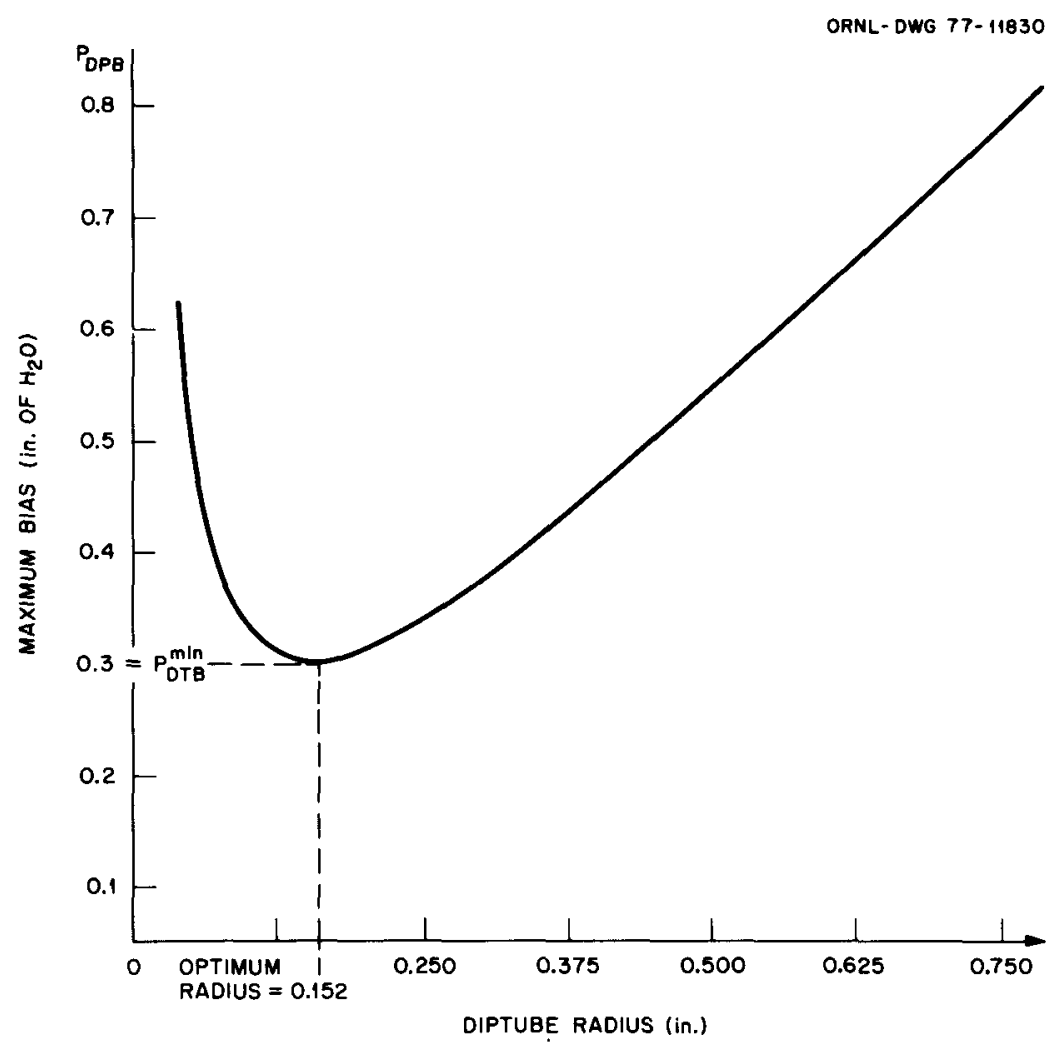

Fig. 4. Calculated maximum dip-tube bias vs dip-tube radius for an air-water system. 


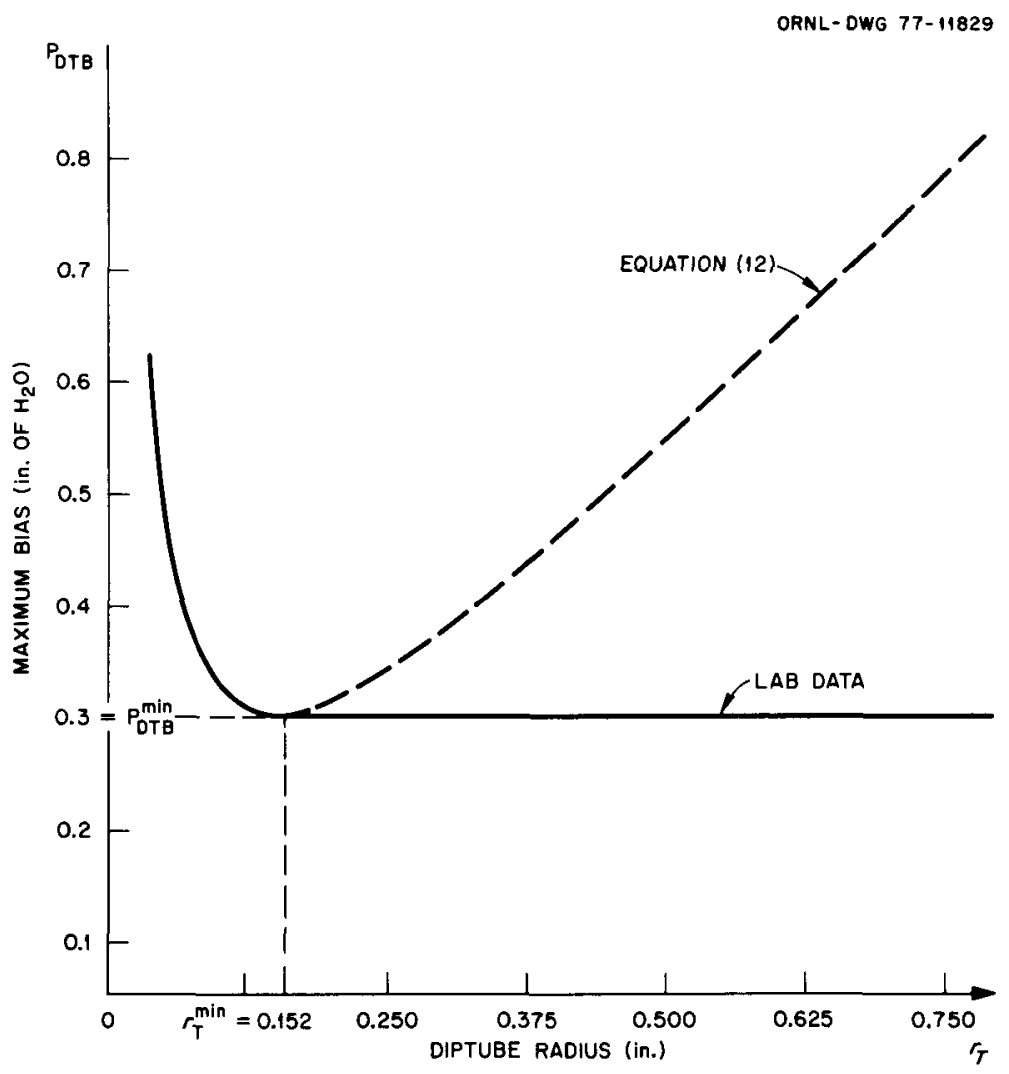

Fig. 5. Comparison of experimental and theoretical dip-tube bias vs dip-tube radius for an air-water system.

Kelly's investigation suggests minimum tube sizes and a scaling relationship for different gas-fluid systems that are in good agreement with the results obtained in this study.

In summary, it is possible to predict the minimum dip-tube bias by the relationship expressed in Eq. (13), and it is also possible to predict the minimum dip-tube radius that will ensure this minimum error by Eq. (12).

\section{OTHER INSTRUMENTATION SYSTEM ERRORS}

Figure 6 shows that the dip-tube pressure error due to bubble pressure is a periodic pressure wave with a typical waveform. The true pressure head that would yield the true height of the fluid above the benchmark has such a superimposed periodic waveform. The indicated pressure will be the result of this composite pressure wave being applied to the instrumentation used for measuring dip-tube pressure. A true averging system will yield an error very close to the dip-tube bias predicted by Eq. (13). An analog or digital instrument could be designed to read the minimum of the transient that would be free of the dip-tube bias pressure.

\subsection{Bubble Rate Effects}

The accuracy of level and density measurements is influenced by errors associated with purge-gas flow rates. It is possible to establish experimentally a range of purge-gas flow rates or 


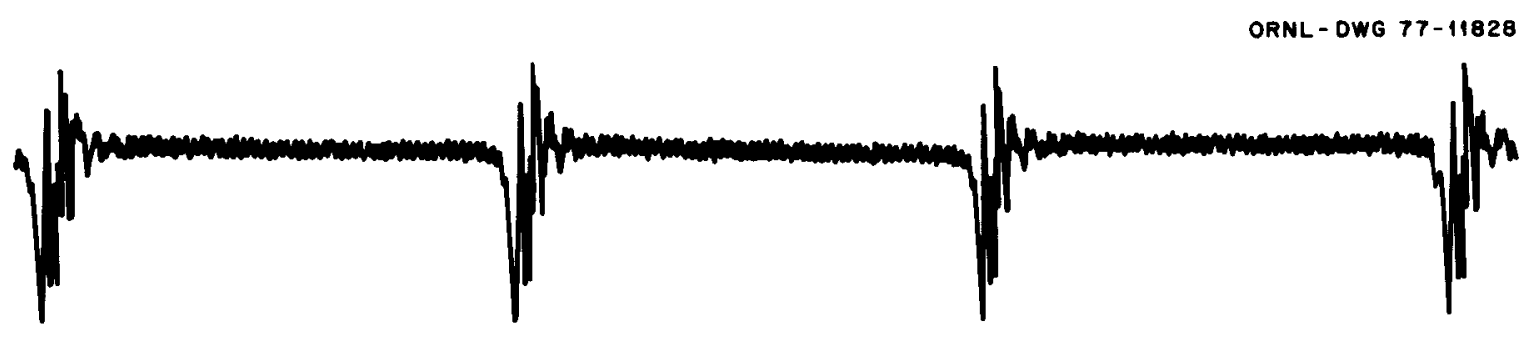

Fig. 6. Dip-tube pressure vs time, showing typical bubble transients.

bubble rates over which the purge-tube pressure remains constant and the bubble pressure transients are measurable. Flow rates below this range do not purge the dip tube and establish a suitable interface. Purge rates above this range cause pressure drops within the purge tube; the ensuing violent bubbling causes mechanical vibrations of the dip tube.

Tests indicated that for air flows in the range of 0.1 to $0.7 \mathrm{scfh}$, the measured dip-tube pressure changed only $\pm 0.25 \%$, even for shallow cases. If the tube depth was increased, the variation was reduced to $\pm 0.1 \%$. These data are consistent with Kelly's ${ }^{3}$ recommendation and with trade literature.

Initial fouling tests indicated that the slow fouling process would not change the bubble rate fast enough to predict impending plugging. The tests did show a large change in the shape of the bubble pressure waveform when very small tube openings were used. This waveform change could serve as a method for detecting potential plugging.

\subsection{Sparging Effects}

The testing described above was done with the dip tubes immersed in a static water column disturbed only by the bubbles from the dip tube itself. Since air sparging is commonly used to mix the contents of vessels, tests were made to assess the effects of such sparging on dip-tube level and density measurements. The results of these tests were (1) that the indicated level increased as the sparging rate increased; (2) a $6 \%$ increase in indicated level was observed for a sparging rate of 78 scfh in a cylindrical vessel with a cross section of $0.196 \mathrm{ft}^{2}$; (3) the bubble waveform was completely masked by the signal noise that the sparging created, even at very low sparging rates; (4) the sparging noise increased as the sparging rate was increased; (5) the indicated density decreased as sparging rate was increased; (6) a $9 \%$ decrease in indicated density was observed for a sparging rate of $81 \mathrm{scfh}$ in a cylindrical vessel with a cross section of $0.196 \mathrm{ft}^{2}$; (7) thorough mixing required the higher sparging rates; and (8) the sparging noise could have resulted from both the splashing effect generated at the surface and the interaction between the sparging bubbles and the dip-tube bubbles. Figure 7 shows the trend between sparging gas flow rate and indicated pressure or depth for a dip-tube system using water and a Statham $d / p$ cell. With no sparging flow, the purge-gas bubbles in the dip tube caused maximum and minimum pressure readings of 90.5 and $92.5 \%$ respectively. These readings correlate well with the blowing of the bubble at the end of the dip tube. As the sparging rate is increased, both maximum and minimum indicated pressures increase and diverge slightly.

Figure 8 shows the trend of density vs sparging rate when two dip tubes are used to measure density in a sparged tank. 


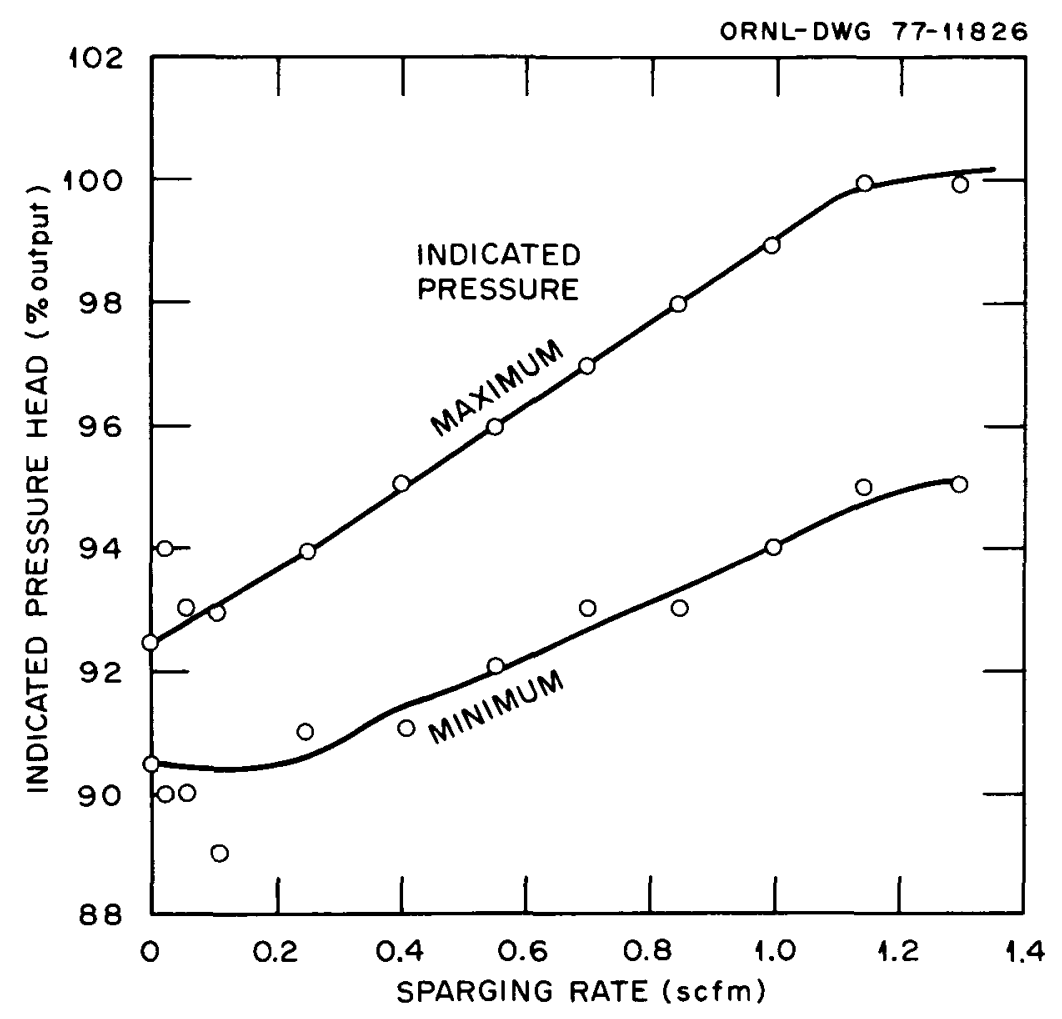

Fig. 7. Effect of sparging flow rate on indicated pressure head.

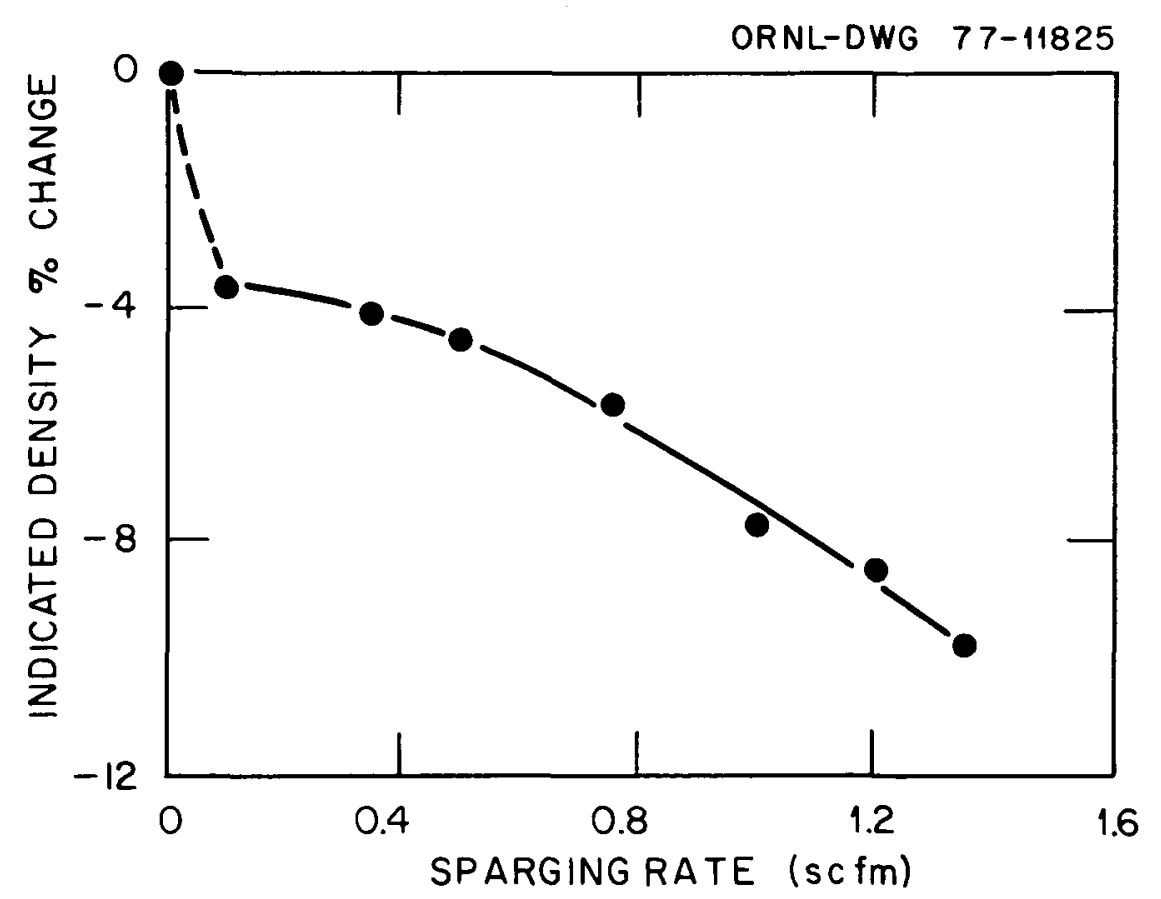

Fig. 8. Effect of sparging flow-rate on indicated density. 


\section{DIP-TUBE PRESSURE SENSORS}

Two approaches are open to the experimenter with respect to measuring dip-tube pressures. The first is to use instrumentation that is sufficiently slow to ensure that the average pressure is indicated. The indicated pressure then will contain a dip-tube bias approaching that predicted by Eq. (10). This statement is based on the observed bubble waveform having an average value close to its peak value.

The second approach is to use pressure instrumentation with a bandwidth suitable enough to indicate the instantaneous dip-tube pressure. The minimum dip-tube pressure then, which is free of the bubble-produced bias, can be deduced. Such a transient system would require analog or digital computing circuits to read the minimum pressure that occurs just as the bubble begins to form.

When the differential pressure between two dip tubes is used to infer the density of a fluid, the time relationship between the two bubbles is important. The dip-tube bias will cancel out if the bubbles are synchronized or if the differential pressure cell measures the true average pressure and does not respond to the bubble transients. It is therefore important to know the dynamic range of the pressure measuring system as well as its accuracy.

The traditional dip-tube level measurement has employed a conventional process-type differential pressure transmitter $(d / p$ cell) with pneumatic or electronic output. Such devices have an accuracy of $\pm 0.5 \%$ of the span (usually $\pm 0.25 \%$ for electronic $d / p$ cells). Pressure transmitters of this type are also usually designed and connected in such a manner that they are slow in transient response and tend to measure the average dip-tube pressure.

As an example of the errors that could be expected using such a level measurement, assume that a water tank $6 \mathrm{ft}$ tall has a dip tube and a $\mathrm{d} / \mathrm{p}$ cell to measure its content, as shown in Fig. 1. The pressure applied to the sensor (without dip-tube bias) is $\Delta P=624 \mathrm{psf}=4.33 \mathrm{psi}$, or $\triangle P=120 \mathrm{in}$. of water. Without dip-tube bias or other errors a perfect $d / p$ cell should indicate a pressure of 120 in. of water. If a span of $120 \mathrm{in}$. were required to allow the tank to be operated with heads of 0 to $10 \mathrm{ft}$, then a d/p cell with $\pm 0.5 \%$ accuracy would have an uncertainty of $\pm 0.005 \times 120= \pm 0.6$ in. of water. This uncertainty must be properly combined with other random errors. A well-designed purged dip tube would have a systematic bubble error predicted by Eq. (13) for an air-water system of 0.3 in. Perhaps one should not worry about a systematic error of 0.3 in. of water if the random errors are in excess of twice that amount. However, if the $d / p$ cell accuracy were improved to $\pm 0.1 \%$ of span, which in this example would be \pm 0.12 in. of water, the dip-tube bias would become significant. The dip-tube bias can be removed or corrected by methods previously discussed.

Density measurements made with two purged dip tubes (Fig. 2) will be subjected to both dip-tube bias errors and pressure-transducer errors since

$$
\rho=\frac{\Delta P}{\Delta h}=\frac{P_{1}-P_{2}}{h_{2}-h_{1}}
$$

If the pressure system responds to average pressure in the dip tubes, then the differential pressure could be made free of dip-tube bias, since both $P_{1}$ and $P_{2}$ in Eq. 14 could contain the same bias. However, the $d / p$ cell error will still be the usual span of $\pm 0.5 \%$.

When using fast pressure instrumentation, the bubbles coming from the two dip tubes need to be synchronized. If they are not synchronized, the differential pressure waveform will be difficult to analyze. However, it may not be possible to synchronize the bubbles. 
In density measurement, a large $\Delta h$ spacing between dip tubes would appear to reduce the relative contribution of dip-tube bias to the pressure being measured for density determination. However, $\triangle h$ spacing may not be useful since it will require a larger pressure-transd ucer span; and since pressure-transducer accuracy is usually tied to the percent of span, the improvement may be lost.

Pressure-transducer errors might be reduced by using split-range pressure transducers or reduced-range pressure transducers with variable zeros or suppression. However, the accuracy of variable zero reference pressures is likely to be poor and to contribute more error than the larger-span transducer with fixed zero.

It is important to select dip-tube lengths, separations, and transducer ranges to minimize the total rms error and to allow the removal of systematic errors.

\section{ERRORS DUE TO TANK GEOMETRY AND TEMPERATURE}

The uncertainty of the volume-height relationship of a tank is significantly influenced by tank geometry as well as tank and content temperatures. It is customary to characterize actual tank deviations from the geometric ideal (usually a cylinder) by properly designed calibration tests. ${ }^{4}$ Temperature effects on the stored liquid and the tank must also be taken into consideration. ${ }^{5}$ It is often justified to correct the fluid density for temperature changes and to neglect other temperature effects. ${ }^{5}$ Very large tanks can have pressure-expansion-induced errors. A cylindrical tank is shown to have a pressure-induced error given by ${ }^{5}$

$$
\text { Error in volume }=\frac{\pi S}{E}
$$

where $S=$ average wall stress, and $E=$ modulus of elasticity. Then,

$$
S=\frac{6 P D}{t} \text { for a cylindrical tank, }
$$

where $P=$ average pressure, $D=$ tank diameter, and $t=$ wall thickness.

As an example, a 10-ft high, 6-ft diameter, 3/8-inch stainless steel wall tank full of fluid with a specific gravity of 1.4 will have a pressure-induced error given by

$$
\begin{aligned}
& \text { Error }=\frac{\pi \times 7.27 \times 10^{-6}}{0.375} \\
& \text { Error }=0.00006=0.006 \% \\
& \text { where } S=\frac{6 \times(10 \times 1.4 \times 0.433) \times 6}{30 \times 10^{6}} \\
& S=7.27 \times 10^{-6}
\end{aligned}
$$


The above tank containing an unstressed volume of

$$
V=\frac{\pi \times(6)^{2}}{4} \times 10=282.744 \mathrm{ft}^{3}, \text { or } 2115 \mathrm{gal},
$$

would be in error only 0.127 gal due to pressure-induced changes in volume for the assumed material properties.

Temperature effects can be significant and are predictable for simple geometries and uniform temperatures. Error equations for common-level measuring systems caused by temperature changes have been reported..$^{5}$ As an example, the above tank when filled with water would change volume $0.026 \%$ or 0.560 gal. for a $10^{\circ} \mathrm{F}$ temperature change by using the equations found in Ref. 5 .

If a pressure transducer with a span of $10 \times 0.4335 \mathrm{psi}=4.3 \mathrm{psi}$ and an accuracy of $0.5 \%$ were used to infer this volume, this error would still be the most significant of the errors considered. Of course, the temperature error could be treated as systematic and removed.

\section{CONCLUSION AND RECOMMENDATIONS}

A simple model for the determination of dip-tube bias based on spherical bubbles was experimentally verified for dip tubes close to the optimum diameter. The model also agreed well with the work of Kelly.

For a carefully designed and calibrated vessel, the total error in the level or density measurement systems was found to be dominated by the inherent error in the differential pressure transducer. This analysis did not consider the error contributions of the recording system that could have a significant impact on overall error. In addition, if the inherent error of the differential pressure transducer were reduced far enough, errors such as variations in density of the purge gas might need some consideration.

Density and level measurement systems should be carefully designed following Kelly's suggestions, thus avoiding introduction of unnecessary errors. Unavoidable systematic errors such as dip-tube bias should be eliminated by careful calibration techniques.

The installation and operation of the dip-tube system should be as carefully accomplished as the design. The interpretation of data obtained under operating conditions should include analysis of conditions significantly different from calibration conditions, such as when sparging is occurring.

Since inherent errors in differential pressure transducers are usually stated as percent of span, the design of the level of density measurement system should attempt to keep the maximum necessary span as small as possible. For example, a level system design using several dip tubes placed at equally spaced intervals of depth and having their depths carefully calibrated would allow level measurements with a $d / p$ cell span equal to the spacing interval instead of the entire depth of the tank. 


\section{REFERENCES}

1. C. Tilford, Gas Density Effect in High Accuracy Liquid Volume Measurements, National Bureau of Standards.

2. N.K. Adam, The Physics and Chemistry of Surfaces, 3d ed., Oxford University Press, London, 1941.

3. M. J. Kelly, "Get Maximum Accuracy from your Dip-Tube Level and Density Systems," pp. 79-80 in Control Engineering, August 1958.

4. H. H. Ku et al., Liquid Level Instrumentation in Volume Calibration, NBS-PB-250 859 (October 1975).

5. D. M. Considine and S. D. Ross, Handbook of Process Instrumentation, May 1963, pp. 5-62-5-65. 

1. R. K. Adams

2. S. M. Babcock

3. S. P. Baker

4. B. J. Bolfing

5. J. T. Bell

6. M. Bender

7. M. R. Bennett

8. R. E. Blanco

9. J. O. Blomeke

10. W. D. Bond

11. B. F. Bottenfield

12. E. C. Bradley

13. N. C. Bradley

14. R. E. Brooksbank

15. K. B. Brown

16-25. W. D. Burch

26. J. M. Chandler

27. H. E. Cochran

28. D. A. Costanzo

29. R. M. Counce

30. D. J. Crouse

31. B. F. Crump

32. F. L. Culler

33. B. C. Duggins

34. J. H. Evans

35. M. J. Feldman

36. D. E. Ferguson

37. S. D. Floyd

38. J. H. Goode

39. J. M. Googe

40. N. R. Grant

41. W. S. Groenier

42. W. R. Hamel

43. D. C. Hampson

44. B. A. Hannaford

45. H. N. Hill

46. W. D. Holland

47. J. O. Hylton

48. A. R. Irvine

49. J. D. Jenkins

50. W. F. Johnson

51. P. R. Kasten
52. L. J. King

53. J. Q. Kirkman

54. J. A. Klein

55. C. E. Lamb

56. B. E. Lewis

57. B. Lieberman

58. L. E. McNeese

59. D. D. McQue

60. G. N. Miller

61. W. P. Murray

62. J. G. Morgan

63. C. A. Mossman

64. E. L. Nicholson

65. E. D. North

66. L. C. Oakes

67. F. L. Peishel

68. H. Postma

69. G. W. Renfro

70. J. E. Rushton

71. W. F. Schaffer, Jr.

72. C. D. Scott

73. A. A. Shourbaji

74. B. B. Spencer

75. M. J. Stephenson

76. D. B. Trauger

77. W. E. Unger

78. V. C. A. Vaughen

79. B. L. Vondra

80. C. D. Watson

81. B. S. Weil

82. T. D. Welch

83. M. E. Whatley

84. J. R. White

85. R. G. Wymer

86. O. O. Yarbro

87-88. Central Research Library

89. ORNL-Y-12 Technical Library, Document Reference Section

90-91. Laboratory Records

92. Laboratory Records, ORNL RC

93. ORNL Patent Office

94. Nuclear Safety Information Center 
96. Director, Reactor Division, DOE-ORO

97-98. Director, Division of Nuclear Fuel Cycle and Production, DOE, Washington, D.C. 20545

99-100. Director, Division of Reactor Research and Development, DOE, Washington, D.C. 20545

101. M. L. Bleiberg, Westinghouse Electric Corporation, Advanced Reactors Division, Waltz Mill Site, P.O. Box 158, Madison, PA 15663

102. R. B. Chitwood, Chief, Industrial Programs Branch, Division of Waste Management, Production, and Reprocessing, DOE, Washington D.C. 20545

103. Duane E. Clayton, Battelle Pacific Northwest Laboratory, P.O. Box 999, Richland, WA 99352

104. Martin Friedland, Gulf + Western Advanced Development and Engineering Center, 101 Chester Road, Swarthmore, PA 19081

105. Jerry M. Friedman, Sandia Laboratories, P.O. Box 5800, Albuquerque, NM 87115

106. Frank J. Jones, Bechtel Corporation, P.O. Box 3965, San Francisco, CA 94119

107. Burt Judson, General Electric Company, Nuclear Energy Programs Division, 175 Curtner Avenue, San Jose, CA 95125

108. R. S. Karinen, Programmed and Remote Systems Corporation, 3460 Lexington Avenue, St. Paul, MN 55112

109. Robert H. Karlsson, Rockwell International, Atomics International Division, Rocky Flats Plant, P.O. Box 464, Golden, CO 80401

110. W. H. McVey, Chief, Technology Branch, Division of Waste Management, Production, and Reprocessing, DOE, Washington, D.C. 20545

111. R. E. Mullen, Aerojet Manufacturing Company, 601 South Placentia Avenue, P.O. Box 4210, Fullerton, CA 92634

112. W. S. Scheib, Jr., Chief Projects Branch, Division of Waste Management, Production, and Reprocessing, DOE, Washington, D.C. 20545

113. D. R. Spurgeon, Acting Assistant Director for Reprocessing, Division of Waste Management, Production, and Reprocessing, DOE, Washington, D.C. 20545

114. D. E. Wood, Kaman Sciences Corporation, 1500 Garden of the Gods Road, P.O. Box 7463, Colorado Springs, CO 80933

115. Research and Technical Support Division, DOE-ORO

116-324. Given distribution as shown in TID-4500 under UC-79c, Fuel Recycle Category (Applied) 